Time and the Keyboard Fugue

Author(s): Keith Chapin

Source: 19th-Century Music, Vol. 34, No. 2 (Fall 2010), pp. 186-207

Published by: University of California Press

Stable URL: http://www.jstor.org/stable/10.1525/ncm.2010.34.2.186

Accessed: 26/02/2014 06:32

Your use of the JSTOR archive indicates your acceptance of the Terms \& Conditions of Use, available at http://www.jstor.org/page/info/about/policies/terms.jsp

JSTOR is a not-for-profit service that helps scholars, researchers, and students discover, use, and build upon a wide range of content in a trusted digital archive. We use information technology and tools to increase productivity and facilitate new forms of scholarship. For more information about JSTOR, please contact support@ jstor.org. 


\title{
Time and the Keyboard Fugue
}

\author{
KEITH CHAPIN
}

In an 1837 review of Felix Mendelssohn's Preludes and Fugues, op. 35, Robert Schumann called his readers' attention to slight but significant differences in fugal technique: "In a word, these fugues have much of Sebastian in them and might make the most sharp-sighted reviewer err, were it not for the melody, the finer smelting in which one recognizes modern times, and here and there those little touches peculiar to Mendelssohn that betray him as the composer among a hundred others." ${ }^{1}$ Beyond

\footnotetext{
1"Mit einem Worte, die Fugen haben viel Sebastiansches und könnten den scharfsichtigsten Redacteur irre machen, wär' es nicht der Gesang, der feinere Schmelz, woran man die moderne Zeit herauserkännte, und hier und da jene kleinen, Mendelssohn eigenthümlichen Striche, die ihn unter Hunderten als Componisten verrathen." Robert Schumann, Gesammelte Schriften über Musik und Musiker, 4 vols. (Leipzig: Georg Wigand, 1854), I, 100. All translations are my own unless otherwise noted. I have provided the original text of quotations from primary sources, but not for those of secondary literature. This article builds on a paper presented at the 2008 annual meeting of the Ameri-
}

noting the "finer smelting" of the melody, Schumann did not say much about the slight differences in technique that distinguished Bach from Mendelssohn, but the significance he found in the technical differences is both striking and illuminating. Schumann saw "modern times" reflected in Mendelssohn's fugues.

Although he spoke primarily as a technician of the fugue when observing Mendelssohn's modern touches and handling of melody, Schumann had more than updates in compositional technique in mind. A year later, he would describe Bach's fugues as "character pieces of the highest art" in a review of Carl Czerny's edition of the Well-Tempered Clavier. ${ }^{2}$ Schu-

\footnotetext{
can Musicological Society, at the Université FrançoisRabelais Tours, and at the Schweizerische musikforschende Gesellschaft in Basel. I thank Lawrence Kramer and Daniel Melamed in particular for their criticisms of the paper. ${ }^{2}$ Schumann, Schriften, III, 5. The review (1838) is appended to a discussion of Czerny's Schule des Fugenspiels und des Vortrags mehrstimmiger Sätze.
} content through the University of California Press's Rights and Permissions Web site, at http://www.ucpressjournals.com/ reprintInfo.asp. DOI: $10.1525 / \mathrm{ncm} .2010 .34 .2 .186$. 
mann was not a critic to restrict himself to technical considerations. The modern times he recognized in Mendelssohn's fugues were as much a matter of mood as they were matters of theme construction, phrasing, or cadence. After all, to speak of the fine smelting (feiner Schmelz) of the melody is to use a metaphor to capture the affective character or mood of the melody and by extension of the whole. The fugues, in other words, produced a mood that had much of Sebastian in it but was also modern and suitable to the nineteenth century. Behind this mood, as behind Mendelssohn's technique of fugue itself, stood a negotiation of past and present, a synthesis of a dual obligation to a tradition posited as timeless and to a principle of historical change that rendered the present different from the past. ${ }^{3}$

Moreover, the mood of modern times was not just the product of Mendelssohn's compositional prowess. Moods exist in people, ultimately, even if they can be provoked by music and other phenomena and thus be attributed to them. As David Wellbery has noted, all theorists of mood (Stimmung) have attributed to it a strong quality of the I (Ichqualität). ${ }^{4}$ In this sense, Schumann's statement about Mendelssohn's fugues says as much about Schumann as it does about Mendelssohn or Bach. The mood he heard emerged not just from technical characteristics but also from an interpretive practice. It was due in part to the way that the fugue manipulates harmony, melody, rhythm, themes, and other technical characteristics, but it also owed much to the way that Schumann listened to and thought about the fugue.

In short, the modernity of Mendelssohn's fugues was equally a matter of Mendelssohn's technique and of Schumann's interpretive prac-

\footnotetext{
${ }^{3}$ On Schumann's view of history, see Carl Dahlhaus, "Klassizität, Romantik, Modernität: Zur Philosophie der Musikgeschichte im 19. Jahrhundert," in Die Ausbreitung des Historismus über die Musik, ed. Walter Wiora, Studien zur Musikgeschichte des 19. Jahrhunderts (Regensburg: Gustav Bosse, 1969), pp. 261-76; Bernhard Meissner Geschichtsrezeption als Schaffenskorrelat: Studien zum Musikgeschichtsbild Robert Schumanns (Bern: Francke, 1985).

${ }^{4}$ David Wellbery, "Stimmung," in Ästhetische Grundbegriffe: Historisches Wörterbuch in sieben Bänden, ed Karlheinz Barck (Stuttgart: Metzler, 2000-05), V, 704.
}

tice. Both were of their time. Yet they were not just of their time. The technique of fugue and the practice of interpretation also worked in time in a way characteristic of their age. Behind Schumann's aperçu stands a question about how the fugue articulates time and how time works in the interpretive process. For through its characteristic articulation of time, the fugue creates a characteristic sound and mood; and through different types of interpretation, the critic will hear the temporal character of the fugue in different ways.

These issues are particularly interesting because the fugue has often stood as a token of durability, of timelessness, as have its affiliates, canon and the stile antico. The homage that Schumann and Mendelssohn paid to Bach's fugues is itself an indication of the transhistorical value that they attributed to the genre, but the critical topos linking the fugue and associated genres and styles with timelessness has a long and multiform history. In 1721 Heinrich Bokemeyer wrote of the canon, "there he [the artist] finds the beginning and end bound together and has discovered the perpetual canon in order to remind himself of the eternal unending origins as well as the harmony of all eternity, a rule of nature of the most perfect example of his artistic work. ${ }^{\prime \prime}$ In the circularity of canon, Bokemeyer found an allegory of the circularity and harmony of eternity. Almost exactly one hundred years later, in 1819, Christian Friedrich Michaelis explained the sublime sentiment elicited by canonic and fugally elaborated works as "based on the manner in which the imagination, striving to comprehend the melody, is held up by the entrances of new voices and, despite the imagination's inclination toward variety and change, is always led back to the one and the similar. By this, reason finds itself stimulated to think of the lasting

\footnotetext{
5"Da findet er nun den Anfang und Ende verknüpffet, und hat den Canonem infinitem, um sich des ewigen und unendlichen Ursprungs, wie auch der in alle Ewigkeit bestehenden Harmonie, zu erinnern, als eine Regul der Natur, zum vollkommensten Muster aller seiner KunstArbeit." Cited in Johann Mattheson, Critica Musica, 2 vols. (Hamburg: Author, 1722-25; facs., Laaber: Laaber, 2003), I, 342-43.
} 
and the eternal." 6 The thematic unity of the fugue and the canon became a symbol under the aspect of the eternal.

The aura of immutability permeated other aspects of musical practice associated with counterpoint and the fugue as well. Friedrich Rochlitz, the founding editor of the Allgemeine musikalische Zeitung, argued that a solid training in fugue would assure the durability of works over time and thus assure their composers of immortality. Like other pedagogues both before and after him, Rochlitz located the topos of timelessness not just in the fugue as a genre but also in the compositional craft it taught. The logic involved was different. It owed something to musicians' desires to protect treasured techniques against changes in style. ${ }^{7}$ But the associations were similar.

Behind Schumann's offhand comment on modern times, then, stands a host of issues governing the relationship between time and the keyboard fugue. ${ }^{8}$ The fugues articulate time

\footnotetext{
${ }^{6 " D i e s s}$ gründet sich auf die Art, wie in solchen Compositionen die nach Umfassung der Melodie strebende Einbildungskraft durch neu eintretende Stimmen aufgehalten, und bey ihrer Neigung zu Mannigfaltigkeit und (Veränderung) immer auf das Eine und Ähnliche zurückgeführt wird, wodurch die Vernunft sich aufgeregt findet, das Bleibende und Ewige zu denken." Christian Friedrich Michaelis, "Etwas zur Rechtfertigung des Contrapunctes," in Michaelis, Ueber den Geist der Tonkunst und andere Schriften, ed. Lothar Schmidt, Musikästhetische Schriften nach Kant (Chemnitz: Gudrun Schröder, 1997), p. 291.

${ }^{7}$ Friedrich Rochlitz, "Die Fuge: Zunächst an Dilettanten und Laien," in Für Freunde der Tonkunst, 4 vols. (Leipzig: Carl Cnobloch, 1824-32), I, 141-77. For other examples of traditionalist polemics against the new, see Johann Joseph Fux, The Study of Counterpoint: From Johann Joseph Fux's Gradus ad Parnassum [1725], trans. Alfred Mann, rev. edn. (New York: Norton, 1971); Heinrich Schenker, Kontrapunkt, 2 vols. (Vienna: Universal, 1910-22); Paul Hindemith, "Sterbende Gewässer [1963]," in Aufsätze, Vorträge, Reden, ed. Giselher Schubert (Zurich: Atlantis, 1994), pp. 314-36.

'Edward Lippman, "Progressive Temporality in Music," Journal of Musicology 3 (1984), 121-41; Reinhold Brinkmann, "In the Time(s) of the "Eroica'," trans. Irene Zedlacher, in Beethoven and His World, ed. Scott Burnham and Michael P. Steinberg (Princeton: Princeton University Press, 2000), pp. 1-26; Keith Chapin, "Strict and Free Reversed: The Law of Counterpoint in Koch's Musikalisches Lexikon and Mozart's Zauberflöte," Eighteenth-Century Music 3 (2006), 102-04; Melanie Wald, "Moment Musical: Die wahrnehmbarkeit der Zeit durch Musik," Das achtzehnte Jahrhundert 30 (2006), 207-20; Karol Berger, Bach's Cycle, Mozart's Arrow: An Essay on the Origins of
} Musical Modernity (Berkeley: University of California through their compositional techniques and thereby create works of a certain character or mood. This character or mood can have a temporal dimension, seeming either to cycle through a lasting moment or to develop teleologically toward a goal. ${ }^{9}$ Furthermore, both the compositional techniques and the character or mood can be timely; they can use up-to-date compositional techniques and can capture the sensibility of the time. Finally, the fugue can symbolize various ideas of time held at bay—of transcendence.

In this article, I will investigate one fundamental shift in the relationship between the keyboard fugue and time. While the shift manifested itself in both compositional and critical practices, it is at root a shift in the approach to time that occurred over the course of the eighteenth and early nineteenth centuries. The historian Reinhard Koselleck has distinguished between cyclical and linear views of timeevents seem either to repeat each other or to differ-and he has noted that the privileged conception of time changed from the cyclical to the linear over the course of the eighteenth century..$^{10}$ Karol Berger has recently argued that Johann Sebastian Bach's fugues suggest cyclical time. They mirror the repetition of historical events within an essentially static divine plan. ${ }^{11}$ David Yearsley has catalogued and analyzed the fascination with allegory among Bach's contemporaries. ${ }^{12}$ The compositional and

Press, 2007); John Butt, Bach's Dialogue with Modernity: Perspectives on the Passions (Cambridge: Cambridge University Press, 2010). For a nuanced discussion of Bach's relationship to modernity, see Butt, Bach's Dialogue, pp. 36-96.

${ }^{9}$ For a succinct discussion of cyclical and linear temporal modes, as well as their combined form (the spiral), see Simone Mahrenholz, "Zeit: Musikästhetische Aspekte," in Die Musik in Geschichte und Gegenwart: Allgemeine Enzyklopädie der Musik, 2nd edn., ed. Ludwig Finscher (Kassel: Bärenreiter and Stuttgart: Metzler, 1994-2008), Sachteil IX, cols. 2231-45.

${ }^{10}$ Reinhart Koselleck, Vergangene Zukunft: Zur Semantik geschichtlicher Zeiten (Frankfurt am Main: Suhrkamp, 1979).

${ }^{11}$ Berger, Bach's Cycle, Mozart's Arrow, pp. 89-129.

${ }^{12}$ David Yearsley, "Alchemy and Counterpoint in an Age of Reason," Journal of the American Musicological Society 51 (1998), 201-43; idem, "Towards an Allegorical Interpretation of Buxtehude's Funerary Counterpoints," Music et Letters 80 (1999), 183-206; idem, Bach and the Meanings of Counterpoint (Cambridge: Cambridge University Press, 2002). 
the interpretive methods invoked by Bach's fugues are consilient with each other, I will argue, because allegory collapses time through its conceptual precision. By contrast, later composers such as Schumann and Mendelssohn staged transformational processes in their fugues and thereby suggested their debt to linear notions of time. Critics of counterpoint and fugue worked in tandem with this compositional approach, for they relied on a symbolic method of interpretation that depended on a temporal process as the mind was moved by powerful and imprecise ideas.

The keyboard fugue offers a good demonstration ground for the music-theoretical part of the study. As a specialist genre, it was not as affected by the changes in performance venue, liturgical context, and audience expectation that decisively influenced vocal and other instrumental genres of counterpoint with the emergence of a public sphere and with the advance of secularization. As a specialist genre, that is, it had an aura of being a pure study in musical processes. The keyboard fugue thus forms a sensitive register of changes in how musicians felt and experienced time-and their times.

In the seventeenth and early eighteenth centuries, musicians treated the keyboard fugue as a highly developed repository of techniques generally used in polyphonic styles, both vocal and instrumental. Critical approaches to counterpoint thus differed little between vocal and instrumental genres. By the early nineteenth century, however, many German musicians were developing their ideas about Bach above all from their experience of his keyboard fugues, through which Bach came to stand as an exemplar of counterpoint as a whole. ${ }^{13}$ When these musicians spoke of counterpoint, they often spoke implicitly of the keyboard fugue. Although there were those who looked to Palestrina and the stile antico or to Handel and the

\footnotetext{
${ }^{13}$ Dahlhaus, "Zur Entstehung der romantischen BachDeutung," in Klassische und romantische Musikästhetik (Laaber: Laaber, 1988), p. 122. Zenck notes that keyboard works were the first to pull Bach from the shadow of specialist concerns and that concerted vocal works were ultimately the ones that gave Bach a public face. Martin Zenck, Die Bach-Rezeption des späten Beethoven (Stuttgart: Steiner, 1986), pp. 4-128.
}

choral fugue, Bach's keyboard fugues had pride of place in the canon. ${ }^{14}$

The Sounds of Time: Texture, Phrasing, and Harmony

Although musicians and critics alike found the fugue a model of durability in part because they perceived little change in the procedures of counterpoint underpinning it - that is, they thought that timeless rules were at issue-the association with eternity also sprang from the characteristic sound produced by fugal techniques. Indeed, the genre would have lost its representative function as a token of immortality if its constitutive musical processes and techniques could not lend themselves to interpretations of timelessness, despite the many aspects of the fugue that afforded interpretations of flux and change. As late-eighteenthand early-nineteenth-century composers sought to translate the fugue into a contemporary musical style, they preserved many of these techniques and thus left the fugue available to interpretations of durability and immutability, even as they often modified details so as to give their fugues a modern sheen and direction.

Christian Friedrich Michaelis's quasi-phenomenological comments on the fugue, quoted above, can provide a point of departure for the genre's time-annulling aspects. As Michaelis saw the matter, the thematic unity of the fugue ran counter to a basic human desire for variety and change, while the combination of voices into a polyphonic web overwhelmed the listener's powers of comprehension and produced a feeling of sublimity. This feeling of sublimity in turn incited the listener to think of the eternal. For example, in Bach's Fugue in

\footnotetext{
${ }^{14}$ Ludwig Finscher, "'. . . gleichsam ein kanonisirter Tonmeister': Zur deutschen Händel-Rezeption im 18. Jahrhundert," in Kanon und Zensur: Beiträge zur Archäologie der literarischen Kommunikation II, ed. Aleida and Jan Assmann (Munich: Fink, 1987), pp. 271-83; Detlef Altenberg, "Thibauts Idee der 'Reinheit der Tonkunst,'" in Studien zur Kirchenmusik im 19. Jahrhundert: Friedrich Wilhelm Riedel zum 60. Geburtstag, ed. ChristophHellmut Mahling (Tutzing: Hans Schneider, 1994), pp. 3547; James Garratt, Palestrina and the German Romantic Imagination: Interpreting Historicism in Nineteenth-Century Music (Cambridge: Cambridge University Press, 2002).
} 
D Major from Book II of the Well-Tempered Clavier (ex. 1), a triple upbeat figure underpins two different motives, one based on a leap, the other on a leap and a scale. The focused play of these motives throughout lends the fugue a constancy of affect: martial regality, to give it a name. The regality changes little, despite modulations to such minor-mode keys as the submediant $\mathrm{B}$ minor and the mediant $\mathrm{F} \#$ minor. To the ear of Michaelis's ideal listener, the lack of variety would have numbed the mind, and the ubiquity of the motives in all the voices would have confounded it. The polyphonic combination reaches great heights in this fugue, where stretto combinations begin already within the first set of fugal entries and increase in density until the climactic peroration (mm. 44-46).

Michaelis was astute in linking the combined effect of monothematicism, affective unity, and replete polyphony to a sense of timelessness. The relative immutability and persistence of the theme match the theory of sublimity to which Michaelis subscribed, a theory that depended on an idea of a transformative moment, traditionally described through the metaphor of a lightening bolt. Although fugues may not have offered the sudden bolts and jolts characteristic of the symphony, they did have their own way of suiting the traditional topoi of sublimity. They seemed to Michaelis to serve as examples of works so well integrated and so unified-indeed too integrated and too unifiedthat they could be described as if they were extended moments, in essence moments extracted from time. In other words, the lack of variety and the difficulty of differentiating the voices allowed a listener to hear the fugue as a single unit, to feel its power as if it were a single, sublime instant. ${ }^{15}$ As we will see, Michaelis would use this description of the fugue's musical character as the foundation for his critical readings of the fugue's significance. Insofar as fugues produced the mental stoppage traditionally associated with the sublime, they

\footnotetext{
${ }^{15} \mathrm{On}$ the role of the figure of the sublime instant in Michaelis's classicist music criticism, see Keith Chapin, "Classicist Terms of Sublimity: Christian Friedrich Michaelis, Fugue, and Fantasy," Ad parnassum: A Journal of Eighteenth- and Nineteenth-Century Instrumental Music 4 (2006), 115-39.
}

forced the listener to think about the transcendent powers that might envelop human experiences and affairs. The sublime experience was an invitation to meditate on metaphysics. ${ }^{16}$

It is possible to extend the list of the musictheoretical characteristics that permitted the keyboard fugue to be heard as if it were an extended instant. Other standard features include the elision of cadences, the submersion of motives and themes in a rhythmic pulse, and the programmatic concentration of harmony. The characteristic treatment of cadences, themes, and rhythm gives the fugue a texture of implacable insistence. The music seems to extend an initial moment rather than to offer change. By contrast, the programmatic treatment of harmony (by which the fugue makes a demonstration of its tonic keyl makes the unfolding of the music centripetal. Events close in on each other rather than open outwards. The initial moment becomes more complex, but it receives relatively little contrast.

The fugue's characteristic approach to cadences has been one of its most frequently noted attributes. Keyboard fugues in particular tend to run right through cadences, to avoid the type of articulations of events that one might find in the sonata. In 1913 August Halm wrote that "the fugue offers less variety [than the sonata]. On top of that, it permits little respite, for it lacks caesuras in which all voices take part. It never releases the listener from its tension."17 In the Fugue in D Major, relatively clear cadential motions mark the tonic $\mathrm{D}$ major $(\mathrm{m}$. 16), the dominant A major (m. 20), the mediant $\mathrm{F} \#$ minor (m. 27), and the return to the tonic $(\mathrm{m}$. 40). Bach emphasizes these tonal moments through shifts in register (m. 40), in number of voices (m. 16), and in type of material (in each

\footnotetext{
${ }^{16}$ While the association of the fugue with church music surely influenced Michaelis in his ascription of sublimity to the genre, he was too influenced by the empiricism of English and Kantian thought to offer anything more than a theory of sublime experience based on the form of experience, not its content.

${ }^{17 " D i e ~ F u g e ~ b i e t e t ~ w e n i g e r ~ A b w e c h s e l u n g, ~ j a ~ n o c h ~}$ obendrein: sie lässt keine Erholung zu, denn es fehlen ihr die Zäsuren, an denen alle Stimmen teilnehmen: sie entlässt den Zuhörer nie aus der Spannung." August Halm, Von zwei Kulturen der Musik, ed. Gustav Wyneken, 3rd edn. (Stuttgart: Klett, 1947), p. 8.
} 

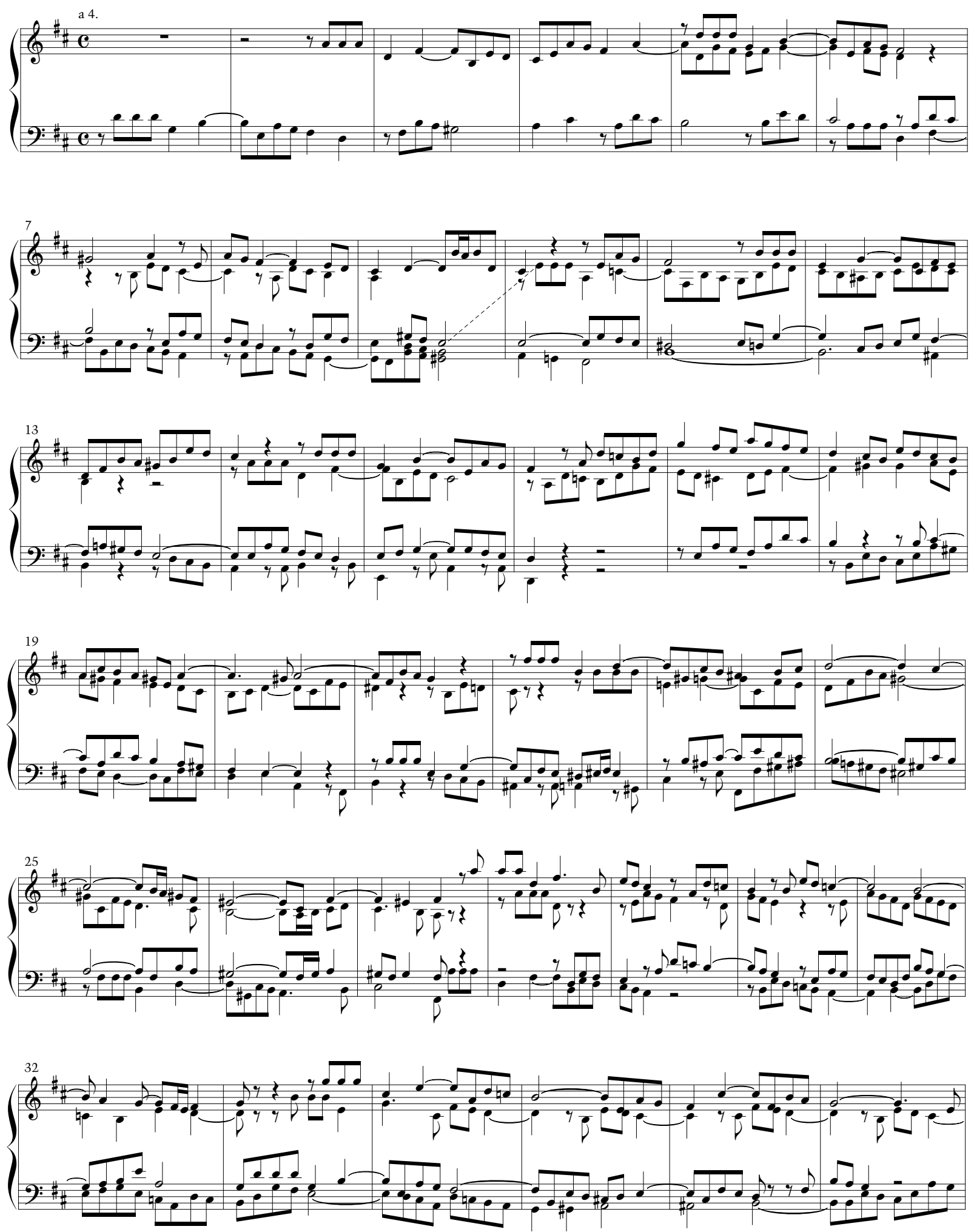

Example 1: Bach, Well-Tempered Clavier, Book II, Fugue in D Major. 


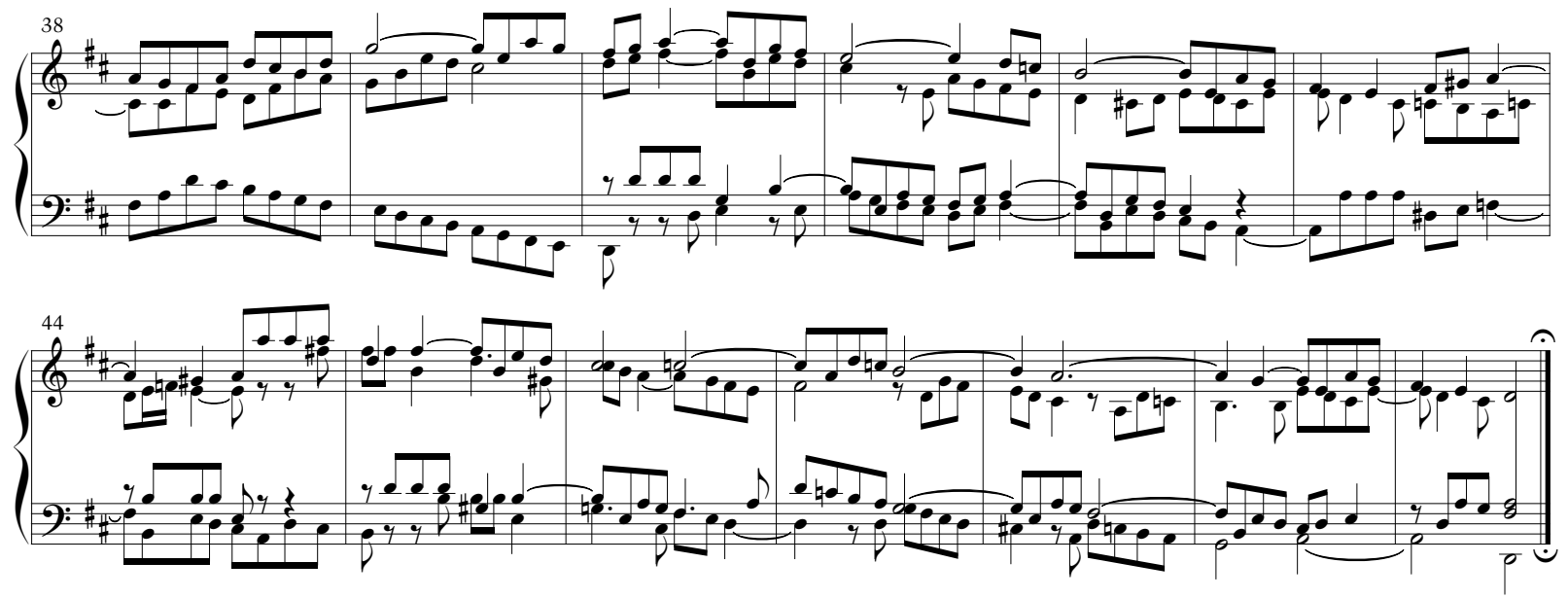

Example 1 (continued)

instance, a shift from subject exposition to episode, or vice versa), but the constancy of eighthnote pulsation nonetheless pushes the music forward through each of the cadences. Events emerge from the texture. They do not occur decisively.

Texture dominates events not only at the broad level of cadences, but also at the local level of motives. Bach formulates counter-subjects so as to complement the subject and to fill out the prevailing rhythm. In this case, there is no set countersubject, as a motive taken from the subject nicely does the trick. The resulting texture is one in which note lengths of the lowest common denominator flow almost constantly. This constancy of motion ensures that the basic pulse retains a certain authority over the pushing and pulling of the motives. As Carl Dahlhaus has written,

the feeling that Bach holds musical events at a distance is not just a vague floating impression of the listener but can also be specified with reference to the music itself. The musical phenomenon on which it is founded is the unbroken and unerring even progress of the music in Bach's works. Individual musical Gestalten do not present themselves with their own individual rhythmic impulse, as in the works of Haydn or Mozart, but rather meld unnoticeably into a rhythm established firmly in the first measure and never brought out of balance by anything that subsequently occurs. One may shy away from metaphysical interpretations of the ongo- ing basic motion-represented most obviously through the thoroughbass. But one cannot deny that the modern aspects of Bach's works are pushed into a distance in which their outlines become unclear. ${ }^{18}$

It may be that Dahlhaus, influenced by a classicist performance tradition, exaggerates the degree of balance involved in a fugal texture, but he is right in his explanation for the topos of objectivity in Bach reception. ${ }^{19}$ Themes and motives never engage in metric revolt.

\footnotetext{
18"Das Gefühl eines Abstands, in dem Bach die musikalischen Ereignisse hält, ist nicht nur ein vage vorschwebender Eindruck des Hörers, sondern läßt sich auch an der Sache selbst präzisieren. Das musikalische Phänomen, auf dem es beruht, ist das ungebrochen und unbeirrbar gleichmäßige Fortschreiten der Musik in Bachs Werken. Die einzelnen musikalischen Gestalten treten nicht, wie bei Haydn oder Mozart, mit einem eigenen, besonderen rhythmischen Impuls auf, sondern fügen sich unauffällig in einen Rhythmus ein, der vom ersten Takt an feststeht und durch nichts, was später geschieht, aus dem Gleichmaß gebracht werden kann. Man mag davor zurückscheuen, die durchgehende Grundbewegung, die äußerlich durch den Generalbaß räpresentiert wird, metaphysisch zu deuten. Aber man kann kaum leugnen, daß durch sie die modernen Momente in Bachs Werke in eine Ferne gerückt wird, in der die Umrisse undeutlich werden." Dahlhaus, "Innere Dynamik in Bachs Fugen," Neue Zeitschrift für Musik 123 (1962), 500.

${ }^{19}$ For a reading of Bach as a mannered modern, again tied to an approach to performance, see Susan McClary, "The Blasphemy of Talking Politics during Bach Year," in Music and Society: The Politics of Composition, Performance, and Reception, ed. Susan McClary and Richard Leppert (Cambridge: Cambridge University Press, 1987), pp. 1362.
} 
This is not to say that the flow rests easily. The opening of the D-Major Fugue could be heard in either the common time used in an early version of the work copied by Altnickol or the alla breve that Bach ultimately decided on. ${ }^{20}$ No matter: what is important is that the figures based on the triple eighth-note upbeat set up a strong pendulum motion in the exposition that is sustained for the rest of the fugue. Once this pulse is established, however, Bach often plays with motives that ride against it. The play begins in $\mathrm{m}$. 7, where the scalar motive moves toward both strong and weak beats. It occurs again in $\mathrm{m} .16$, and in general it is not difficult to find per arsin et thesin reinterpretations of motives. They thus support the polyphonic plenitude that inspired the awe of the sublime in Michaelis. Yet the plenitude is textural, not metric. Even when the motive is uncoupled from its metric context, it accompanies other motivic motions that anchor the broad duple time. Moreover, the bass never rides against the meter as the upper three voices do. Throughout the fugue, the bass emphasizes the strong beats of the measure, so that harmonic and metric foundations of the fugue support each other.

To say that Bach retains an underlying regularity of pulse is not to deny him his composition against the grain, to use Lawrence Dreyfus's phrase, but only to note that the basic alternation of thesis and arsis, or downbeat and upbeat, is strong enough to ensure that subtle emphases on weak beats point up the power of the pulse rather than overturn it. ${ }^{21}$ Like other contrapuntal artifices, such as inversions, retrogrades, and canons of various dimensions, the subject per arsin et thesin demonstrates mastery of harmony, the technical and aesthetic point of most fugues until early in the eighteenth century, when empirically minded critics pooh-poohed the high-flown claims of

\footnotetext{
${ }^{20}$ David Ledbetter, Bach's Well-Tempered Clavier: The 48 Preludes and Fugues (New Haven: Yale University Press, 2002), p. 258. David Ledbetter has suggested that Bach chose the alla breve signature, more appropriate to stile antico fugues, to ensure that performers did not parse the measure with too heavy a hand.

${ }^{21}$ Laurence Dreyfus, Bach and the Patterns of Invention (Cambridge, Mass.: Harvard University Press, 1996), pp. 33-58.
}

the genre's champions. The demonstration arises in part through the art of contrapuntal combination and in part through the reinterpretation of tonally inflected melodic events in a new metric context. Because the technical and aesthetic point of the fugue is harmony, the point of the subject per arsin et thesin is to show the ability of the musician to move the theme without upsetting the pulse.

The cultivation of such harmony in various forms is another feature of the fugue that allows it to annul the passage of time. Harmony, and especially tonal harmony, may propel desire and effect change, but it also provides the means of changing the character of such propulsion. ${ }^{22}$ Fugue and other contrapuntal genres, especially the ricercar, had long served specialist musicians as demonstration pieces in the composition of musical works in the strong sense of the word..$^{23}$ Insofar as these musicians treated the entity as a work, they closed its time off from the time that precedes and follows. Through harmony, they could close off musical time (through returns to the tonic), control the centrifugal tendencies of modulation (by limiting structural modulations to keys closely related to the tonic), and control the relationship between contrapuntal lines (through the privilege assigned to consonance and the control of dissonance). Although many genres drew upon these techniques, the fugue is perhaps unique in the degree to which the ideal of harmony informs the thematic material and the principles by which that material is deployed. Harmony receives programmatic and demonstrative treatment in the fugue subject itself, in its characteristic mode of presentation, and in its various recombinations with itself.

In the eighteenth century, fugue subjects frequently defined the tonality of a piece without the aid of any accompaniment. Elaborations of the tonic triad or of a defining scalar segment

\footnotetext{
${ }^{22}$ Wilhelm Seidel, Werk und Werkbegriff in der Musikgeschichte (Darmstadt: Wissenschaftliche Buchgesellschaft, 1987), pp. 44-66.

${ }^{23}$ John Butt, "The Seventeenth-Century Musical 'Work,',' in The Cambridge History of Seventeenth-Century Music, ed. Tim Carter and John Butt (Cambridge: Cambridge University Press, 2005), pp. 28-31.
} 
of a key often delineated a "melodic tonality," as Roger Bullivant has termed the principle. ${ }^{24}$ The subject of the Fugue in D Major is a relative exception. The fall of a fifth to $G$ and subsequent rise to $\mathrm{B}$ feint toward the subdominant, only to receive a correction by the answer, where the subdominant emphasis is replaced by a tonic one and a short codetta brings the tonic back before the third voice enters. In retrospect, both $\mathrm{G}$ and $\mathrm{B}$ close in on $\mathrm{A}$, squeezing the pitch toward the fifth scale degree and then down toward the third $(F \#)$. The subject has a IV-V-I cadential progression as its organizing principle; the key of the piece is never really in doubt.

The subject and answer may also emphasize the tonal nodes of the piece (tonic and dominant for the eighteenth-century fugue), and thereby announce functional harmony as if the fugue were a programmatic statement or music-theoretical manifesto. In a regular roundrobin, the first voice of our sample fugue begins on $\mathrm{D}$, the second on $\mathrm{A}$, the third on $\mathrm{D}$, the fourth on A. It would be easy to overlook the point of such technical characteristics of the fugue: tonal and real answers, the artful exchange of first and fifth scale degrees, and the maintenance of interval relationships within fugue subject. They are extreme practices of musical introversion. They work to overcome time by creating an intimate link between a theme and its continuation, so that the continuation appears not as something new but only as a cyclical return of what has been before. Neither thematic transformation nor the thematic marking of modulatory journeys is a primary concern. That is reserved for thematic combination, which, as Ulrich Siegele, Lawrence Dreyfus, and Karol Berger have noted, is the ruling tendency in Bach's fugues. ${ }^{25}$ In addition to encouraging continuity of texture and mood, and hence the annulment of time, the features of fugal writing cultivated by Bach

\footnotetext{
${ }^{24}$ Roger Bullivant, Fugue (London: Hutchinson, 1971), p. 40.

${ }^{25}$ Ulrich Siegele, "The Four Conceptual Stages of the Fugue in C Minor, WTC I," in Bach Studies, ed. Don O. Franklin (Cambridge: Cambridge University Press, 1989), pp. 197224; Dreyfus, Bach and the Patterns of Invention, pp. 16988; Berger, Bach's Cycle, Mozart's Arrow, pp. 89-102.
}

mask the characteristics of fugue that admit of flux. They divert attention from the eponymous "flight" (Latin fuga) of voices and from the intensification of thematic density and harmonic complexity over the course of the composition.

Yet such flux should not, and eventually could not, be ignored. As just noted, Fuga is Latin for "flight," and the name shows that the fugue can be heard as a model, not of stasis, but of change. The subject (dux, leader) flees the answer (comes, follower), whether in the constant imitation of a canon or the more fleeting imitations of the fugue. The relationship between the flight of voices and models of temporal flux can also be seen in the use that many later composers found for their study of Bach's fugues. As Dahlhaus observed, nineteenth-century composers broke down Bach's fugues into their constituent techniques in order to press the genre into new service, notably for dynamic development and cathartic codas. ${ }^{26}$ Mozart, Beethoven, Schumann, Wagner, and many others studied the fugue to learn the processes of motivic-thematic working and development in general. ${ }^{27}$ Heard in the right way or in the right context, the constancy of theme could appear less as a static arabesque than as a fluctuating teleology.

\footnotetext{
${ }^{26}$ Dahlhaus, Die Musiktheorie im 18. und 19. Jahrhundert: Erster Teil: Grundzüge einer Systematik, Geschichte der Musiktheorie, vol. 10 (Darmstadt: Wissenschaftliche Buchgesellschaft, 1984), p. 173.

${ }^{27}$ On the differences between the leading of themes through a contrapuntal texture and motivic-thematic working, see Stefan Kunze, Wolfgang Amadeus Mozart: Sinfonie G-Moll, KV 550 (Munich: Fink, 1968), pp. 119-28; Nicole SchwindtGross, Drama und Diskurs: Zur Beziehung zwischen Satztechnik und motivischem Prozeß am Beispiel der durchbrochenen Arbeit in den Streichquartetten Mozarts und Haydns (Laaber: Laaber, 1989), pp. 13-22. The literature on Bach reception is very large; valuable studies of the compositional wisdom that later composers drew from Bach include Matthew Dirst, Bach's Well-Tempered Clavier in Musical Thought and Practice, 1750-1850 (PhD diss., Stanford University, 1996); William Kinderman, "Bachian Affinities in Beethoven," in Bach Perspectives 3: Creative Responses to Bach from Mozart to Hindemith, ed. Michael Marissen (Lincoln: University of Nebraska Press, 1998), pp. 81-108; Charles Rosen, The Romantic Generation (Cambridge, Mass.: Harvard University Press, 1995), pp. 279-360; Christian Thorau, "Richard Wagners Bach," in Bach und die Nachwelt: Band 2: 1850-1900, ed. Michael Heinemann and Hans-Joachim Hinrichsen (Laaber: Laaber, 1999), pp. 163-99.
} 
A second feature of many fugues that favors flux is the tendency to build toward climaxes. These climaxes could be achieved through culminating strettos, as theorists of fugue such as Bononcini and Reincken suggested as early as the seventeenth century, or more generally through the heightened levels of activity, noted more recently by Joel Lester. ${ }^{28}$ The D-Major Fugue engages in stretto from the beginning, yet still saves the most dramatic instance for the end. The first two entries of the subject are separated by the time of three half notes, but the third and fourth (mm. 5-7) already collapse the distance to two half notes. The exposition thus announces stretto as its program and develops it systematically as the fugue progresses. After the first contraction the distance squeezes further down to a single half note (m. 14) and finally to a quarter note (m. 27). This last stretto occurs just past the midway point, after which the fugue occupies itself with ever more dramatic arrangements of the contracted stretto at the quarter note. The pivotal instance at $\mathrm{mm}$. 27-29 involves only two voices (though motives derived from the subject mimic a third); the next adds a third voice (mm. 33-35); and the final instance engages all four voices in a stretto that cascades from the highest pitch of the piece downward (mm. 44-46). These strettos also work toward harmonic complexity. The first maps out D major; the second strongly points toward the subdominant $\mathrm{G}$ major by $\mathrm{m}$. 35 , but muddies the modulation through a dramatic fall of a diminished fifth to the tonic's leading tone ( $\mathrm{G}$ to $\mathrm{C \sharp}$ ); and the third returns to the tonic but invokes ambiguities around both the dominant and the subdominant. The final stretto dissolves downwards into the final cadence and thereby rescinds some of the sense of arrival. ${ }^{29}$

\footnotetext{
${ }^{28}$ Paul M. Walker, "Stretto," Grove Music Online; Oxford Music Online, http://www.oxfordmusiconline.com/subscriber/article/grove/music/26948 (accessed 17 October 2010). Joel Lester, "Heightening Levels of Activity and J. S. Bach's Parallel-Section Constructions," Journal of the American Musicological Society 54 (2001), 68-69. See also Berger, Bach's Cycle, Time's Arrow, pp. 96-98.

${ }^{29}$ Joseph Kerman notes a similar effect at the end of the first fugue of the Well-Tempered Clavier, Book I. Joseph Kerman, The Art of Fugue: Bach Fugues for Keyboard, 1715-1750 (Berkeley: University of California Press, 2005) p. 9.
}

The techniques of fugue, then, lend themselves both to cyclical explorations and to linear developments. On the one hand, the fugue plumbs an affective state as it combines its themes; on the other, it marshals its combinations into an order that does indeed lead somewhere, whether to a climax, or, as is the case here, to a climax followed by an anticlimax. Through their modifications of traditional fugal procedures, nineteenth-century fugues throw the relative timelessness of the keyboard fugue into oppositional relief, usually by finding ways to emphasize climaxes and goals. Beethoven, Mendelssohn, Schumann, and other composers self-consciously took issue with the fugue as they sought to turn it toward their expressive ends. The fugue became ever less a token of being and ever more one of becoming.

Composers staged such becoming most spectacularly through dramatic shifts in texture and mood over the course of the fugue, at times accompanied by a concomitant acceleration of tempo. Schumann's first Fugue, for organ on the name BACH, op. 60 (1845), draws attention to its own fine flow through a tonally ambiguous "characteristic" theme, through the acceleration of tempo, and through a gradual shift from polyphony toward homophony. Schumann deploys the theme itself so as to suggest transformation: the chromatic opening on the pitches $\mathrm{B} b, \mathrm{~A}, \mathrm{C}, \mathrm{B}$ a intimates minor modes and strange harmonies (the supertonic, and in the answer, the submediant, though the exact tonal regions seem less important than the quality of chromatic alienation). The chromaticism of this opening gives way to a triumphant turn to the tonic, and the sense of triumph increases with the completion of each entry of the subject (ex. 2). Schumann's treatment of the BACH theme thus not only pays homage to a composer of the past but also suggests a metamorphosis. By contrast, J. S. Bach himself introduced the $\mathrm{BACH}$ theme in the Art of Fugue as the fourth subject of a quadruple fugue in a minor mode. The theme's chromaticism does little to sway the pervasive, somber $\mathrm{D}$ minor that dominates the fugue and the Art of Fugue in general.

The heroic narrative of struggle toward triumph is also mapped out in Schumann's piece as a whole. The central way stations on this path are the acceleration of tempo and the in- 


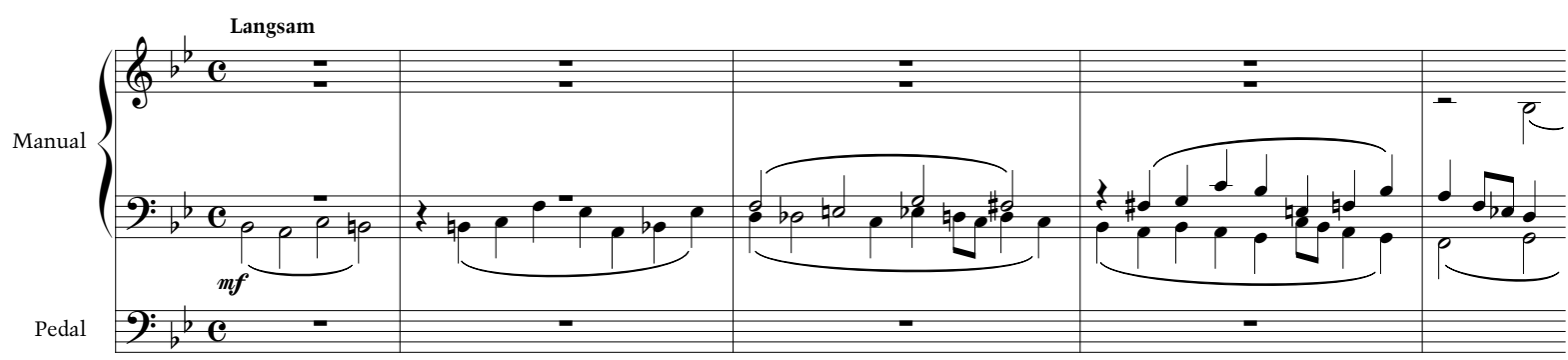

Example 2: Schumann, Fugue No. 1, op. 60 (Fugues on the Name BACH), first two subject entries, mm. 1-5.

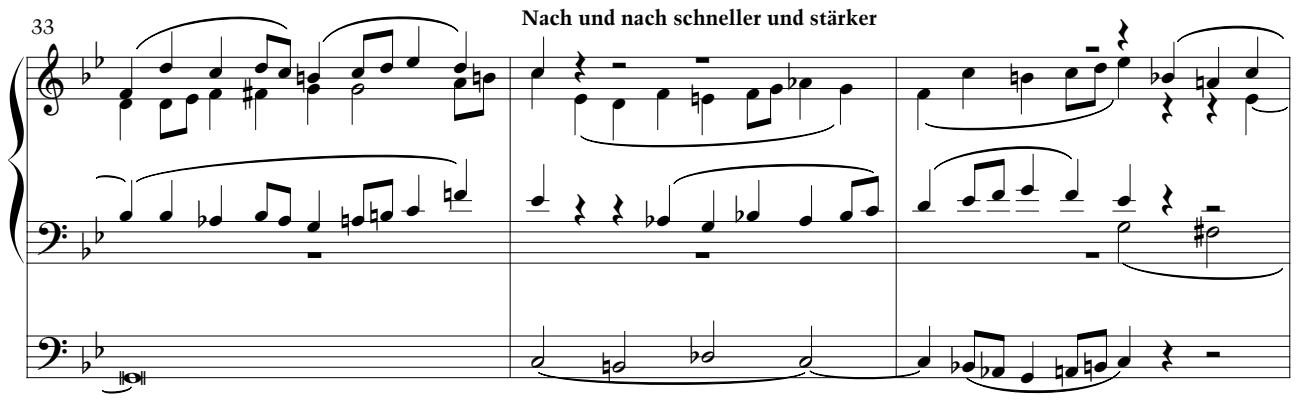

Example 3: Schumann, Fugue No. 1, mm. 33-35.

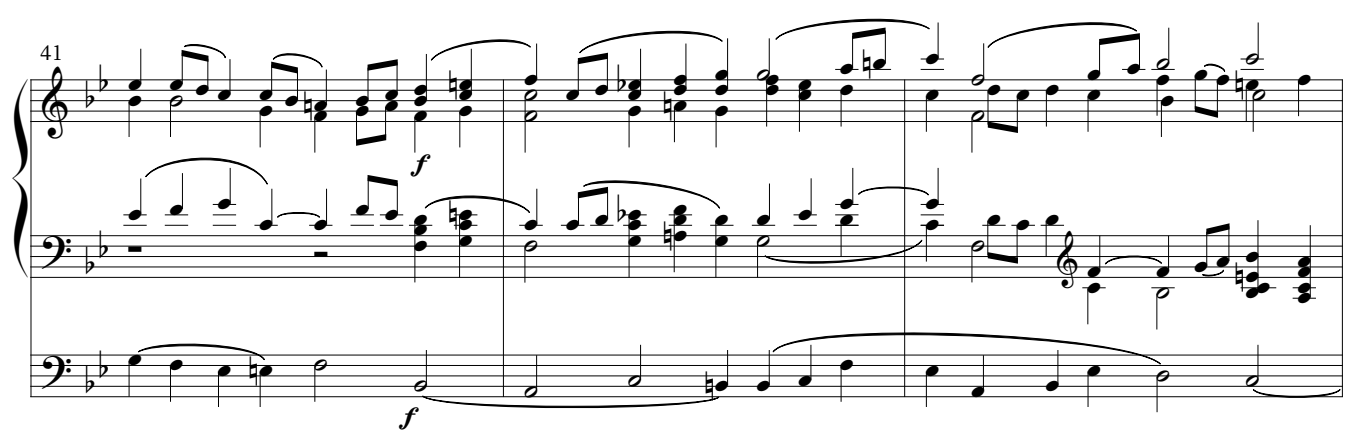

Example 4: Schumann, Fugue No. 1, mm. 41-43.

crease in volume (Nach und nach schneller und stärker, mm. 34ff.; ex. 3) and, most spectacularly, the shift toward homophony at the end. For much of the fugue, Schumann follows Bach's usual practice in the Well-Tempered Clavier: he maintains the number of voices established in the opening entries. In this case, there are five voices, four in the manuals and one in the pedal. (In his own fugues for organ Bach tended to worry less about the strict maintenance of the number of voices.) But at $\mathrm{m} .41$, Schumann adds two extra voices and thereby dramatically changes the texture (ex. 4), and in the rest of the fugue he freely adds voices to create distinct moments of climax. Although the polyphonic combination of the theme with itself and with motives drawn from it does not cease, it is increasingly submerged in full-voiced chords. The increase in tempo accentuates the shift toward homophony; as the pulse shifts from the half note to the half measure, the snaking of the theme becomes less thematic and more ornamental (ex. 5). One hears chords ever more and the polyphonic web ever less. As 


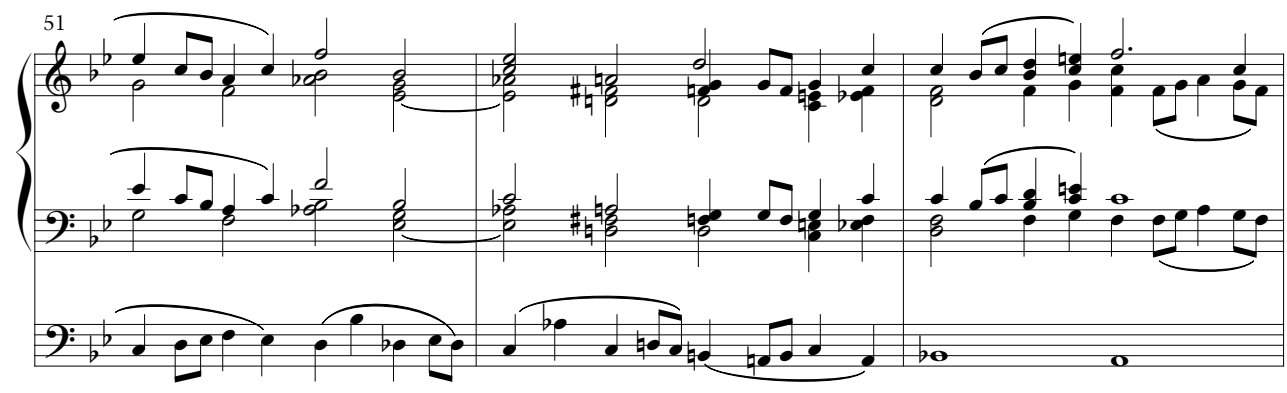

Example 5: Schumann, Fugue No. 1, mm. 51-53.

the fugue grows in sonorousness, speed, and simplicity, it seems to overcome the chromatic polyphony of the opening. The fugue dramatically stages becoming, in both the theme and the overall design.

Such attention to transformation was not uncommon at the beginning of the nineteenth century. Schumann's other five Fugues on the name BACH, op. 60, stage similar metamorphoses. All move toward homophony at the end (though to varying degrees). The quick and playful No. 5 works toward its ending with wry wit. The last, No. 6, mirrors the first fugue in its move toward cathartic homophony through an acceleration in tempo. Nor was Schumann alone in this practice. In the first of his op. 35 Fugues, Mendelssohn dramatically accelerated from fugue to chorale (ex. 6a-c), and in others of the set he used changes in character and texture to mark vital differences between beginning and end. ${ }^{30}$

\section{The INTERPRETATION OF TIME: Allegory ANd Symbol}

Although compositional technique may suggest changes in the way musicians experienced time and sought to articulate it in music, the significance that one finds in the fugue depends to a large degree on the process of inter-

\footnotetext{
${ }^{30}$ On Mendelssohn's approach to the fugue, see Rudolf Stephan, "Über Mendelssohns Kontrapunkt," in Das Problem Mendelssohn, ed. Dahlhaus (Regensburg: Bosse, 1974), pp. 201-07; R. Larry Todd, "Me voilà perruqué: Mendelssohn's Six Preludes and Fugues Op. 35 Reconsidered," in Mendelssohn Studies, ed. R. Larry Todd (Cambridge: Cambridge University Press, 1992), pp. 162-99.
}

pretation itself. Fugue, canon, and other extreme forms of polyphony have long been seen as a sign of transcendentals: God and empire, ${ }^{31}$ the Volk, ${ }^{32}$ objectivity, ${ }^{33}$ the long tradition, ${ }^{34}$ Schopenhauer's Will, ${ }^{35}$ or even, if one takes a musician like Hindemith, something vaguely resembling a Green Party musical environmentalism. ${ }^{36}$ However, it is not the music alone that reveals the worldview, but the music and the mode of interpretation taken together.

\footnotetext{
${ }^{31}$ Johann Joseph Fux, Gradus ad Parnassum (Vienna: Joannis Petri van Ghelen, 1725). See Friedrich Riedel, "Der 'Reichsstil' in der deutschen Musikgeschichte des 18. Jahrhunderts," in Bericht über den Internationalen Musikwissenschaftlichen Kongreß Kassel 1962, ed. Georg Reichert and Martin Just (Kassel: Bärenreiter, 1963), pp. 34-36.

${ }^{32}$ Johann Nikolaus Forkel, Allgemeine Geschichte der Musik, 2 vols. (Leipzig: Schwickert, 1788-1801), I, 47-48. ${ }^{33} \mathrm{E}$. T. A. Hoffmann, E. T. A. Hoffmann's Musical Writings: Kreisleriana, The Poet and the Composer, Music Criticism, ed. David Charlton, trans. Martyn Clarke (Cambridge: Cambridge University Press, 1989), pp. 105 and 113. For the Romantics, objectivity was a double-edged sword. In his "Highly Random Thoughts," Hoffmann describes the rules of counterpoint as fixed entities comparable to the fixed ratios of proportion, but he also enthuses over contrapuntal music as inspired by mystical rules that elicit horror.

${ }^{34}$ Rochlitz, "Die Fuge: Zunächst an Dilettanten und Laien," pp. 141-77.

${ }^{35}$ Ernst Kurth, Grundlagen des Linearean Kontrapunkts: Bachs melodische Polyphonie, 2nd edn. (Berlin: Max Hesses, 1922).

${ }^{36} \mathrm{Paul}$ Hindemith linked his poetics and aesthetics of music to a metaphysics of musical materials and human practices of making and hearing music. Hindemith, The Craft of Musical Composition, trans. Arthur Mendel and Otto Ortmann, 2 vols. (Mainz: Schott, 1941-42), I, 15-16; idem, A Composer's World: Horizons and Limitations: Charles Eliot Norton Lectures, 1949-1950 (New York: Anchor, 1961), pp. 239-57; idem, "Sterbende Gewässer," pp. 314-
} 36. 
a. $\mathrm{mm} .1-3$.

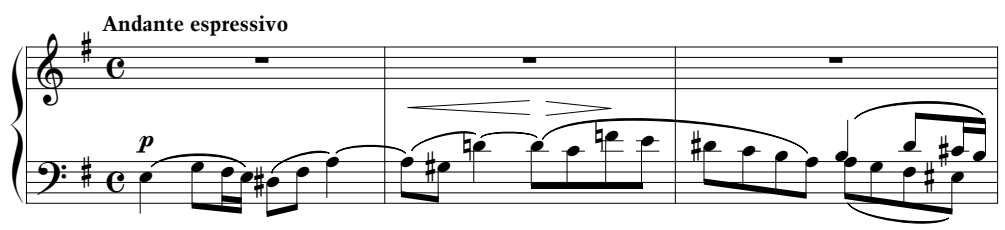

b. mm. $58-59$.

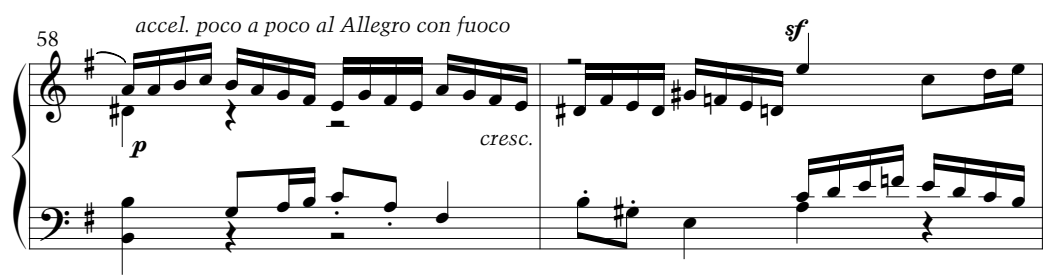

c. mm. 104-07.

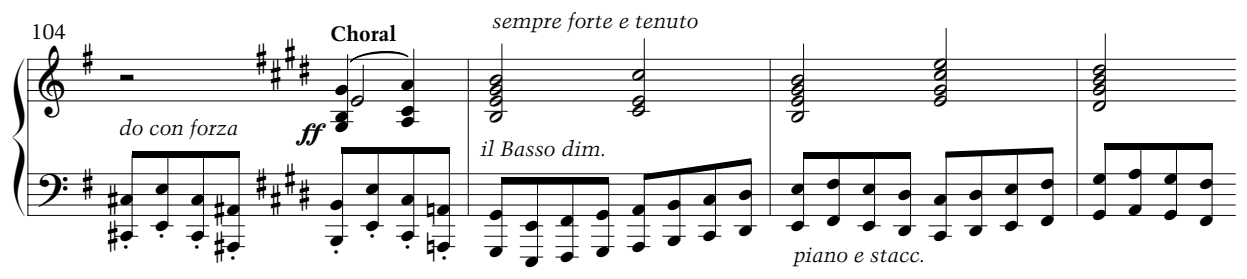

Example 6: Mendelssohn, Preludes and Fugues, op. 35, Fugue No. 1.

Bach's tendency in his keyboard fugues to study his subject, to avoid the emphatic articulation of events, and thus to produce temporal cycles coincides with the prevalent interpretative strategy of his time: allegory. By contrast, Schumann's tendency to stage dramas of becoming in his fugues is consilient with the favor given to symbols by his contemporaries. Where allegory crystallizes time and events into a conceptual image and thereby annuls time, symbol opens up a potentially infinite process of interpretation in which one wheels through the possible consummations of an aesthetic idea.

Karol Berger has taken up the distinction between allegory and symbol to differentiate between the systems of metaphysical thought available to Bach and to Mozart. God was a certainty for Bach, and from this theological certainty one could derive moral laws. By contrast, Immanuel Kant argued that God was impossible to know, but one was morally required to think of his existence. God was an idea of reason. In Berger's neat formulation: for Bach, harmony was a metaphor for God; for Goethe, God was a metaphor for harmony. ${ }^{37}$ In other words, before philosophical skepticism spread, allegories carried the weight of conviction and dealt in the coin of rational certainties. Once skepticism spread, symbols intimated truths of a different order.

If one turns from the ontological differences between allegory and symbol to the practice of interpretation, one finds that the difference of approach has great influence on how one hears and understands music. The interpretive strategy has the effect of pushing the music along the continuum between stasis and teleology in one direction or the other. In an allegorical interpretation, Bach's music appears less teleological than it does in a symbolic one. For this reason, an allegorical interpretation can downplay the undeniable eschatological teleology and musical processuality in Bach. A symbolic in-

\footnotetext{
${ }^{37}$ Berger, Bach's Cycle, Mozart's Arrow, pp. 127-29.
} 
terpretation can emphasize the same teleology in Schumann's fugues. Such differences can also influence performance style, making Bach's fugues now architectural, now fluid and flowing. ${ }^{38}$

To grasp the foundation of the distinction, one can turn to the famous definitions of allegory and symbol made by Johann Wolfgang von Goethe in 1807. With "allegory" Goethe neatly captured the rationalist tendency of the aesthetics and criticism of the early and mid-eighteenth century; with "symbol" he showed his allegiance to an entirely different set of presuppositions about how the mind relates to its world. Of course, the terms themselves have proved quite flexible (not to say slippery) over the course of history. What is important in Goethe's distinction is the role of time in interpretation, not the terms per se.

In allegory, Goethe argued, a sign points to a concept. More exactly, as he wrote in a notebook, "allegory transforms a phenomenon into a concept, and the concept into an image, but in such a way that the concept is limited and can always be had and held completely in the image and can be expressed through it." 39 What is significant in this brief characterization is the limitation of the concept (Begriff). The concept carries precision with it. In more philosophically pregnant language, Immanuel Kant wrote that concepts were "functions" based on "the unity of the action by which different representations are ordered under a common one." 40 The concept crystallizes thought. In its

\footnotetext{
${ }^{38}$ Hermann Danuser, "Dom und Strom: Bachs cis-MollFuge (BWV 849) und die Ästhetik des Erhabenen," in Musikästhetik und Analyse: Festschrift Wilhelm Seidel zum 65. Geburtstag, ed. Michael Märker and Lothar Schmidt (Laaber: Laaber, 2002), pp. 105-34.

${ }^{39 "}$ Die Allegorie verwandelt die Erscheinung in einen Begriff, den Begriff in ein Bild, doch so, daß der Begriff im Bilde immer noch begränzt und vollständig zu halten und zu haben und an demselben auszusprechen sei." Johann Wolfgang von Goethe, Schriften zur Kunst: Schriften zur Literatur: Maximen und Reflexionen, "Hamburger" Ausgabe, 14 vols. (Hamburg: Wegner, 1953), XII, no. 1112. 40"Alle Anschauungen, als sinnlich, beruhen auf Affektionen, die Begriffe also auf Funktionen. Ich verstehe aber unter Funktion die Einheit der Handlung, verschiedene Vorstellungen unter einer gemeinschaftlichen zu ordnen." Immanuel Kant, Kritik der reinen Vernunft, ed. Wilhelm Weischedel, 2 vols. (Frankfurt am Main: Suhrkamp, 1974), I, 109 (Akedemie-Ausgabe, pp. A68/B93).
}

ability to capture thought, allegory was aligned with imitation, which shared the tendency to seek clarity and correspondence. To discover "imitation" was to attend to correspondences between signifiers and signifieds in such a way as to render the process of perception and cognition invisible.

Gerhard Kurz has discussed the relationship between acts of understanding (Verstehen) and allegory. While the sense that the meaning of allegory is fixed and independent of interpreters is a misunderstanding, he notes, it is one that says much about allegory. "In actuality, we have the impression of an independent meaning because an interpretive act has already occurred. However, it is an interpretive act that fits into the expectation of understanding in such a way that it does not seem to have taken place." ${ }^{41}$ In other words, one may require time to decipher an allegory, but the character of the significance espied is such that the time taken seems irrelevant. The endpoint of interpretation is indeed a point, not an ever-vanishing horizon in a process of understanding.

In his portrayal of allegory, Goethe consummated a tradition of aesthetics that tended to emphasize visual models of perception and thus to deemphasize the action of time. In other words, his definition of allegory was as much retrospective as it was a description of an ongoing practice. The allegorical tradition depended on the presupposition that proper thought traded in clear ideas, each one crystallized into an entity. Visual metaphors helped philosophers to emphasize the crystallization. In the early eighteenth century, writers on perception and cognition tended to classify ideas along two axes: clear (klar) and obscure (dunkel) on the one hand, and distinct (deutlich) and indistinct/ fused (undeutlich/verworren) on the other. Although the vocabulary and the construal of the axes varied from writer to writer, all agreed that perception needed to attain clarity in order to count as cognition. The primary difference between aesthetic and rational cognition lay in the opposition between the distinct and the indistinct (or fused) perception of an entity. In

\footnotetext{
${ }^{41}$ Gerhard Kurz, Metapher, Allegorie, Symbol (Göttingen: Vandenhoeck \& Ruprecht, 1982), p. 30.
} 
distinct perception, one perceived all the features of a whole. The distinctness allowed one to understand the entity. In an indistinct perception, the features seemed confused, that is, "fused" together. They could not be distinguished. But the cloud of fusion carried a lining of aesthetic silver: in the absence of the rational understanding of distinct features, the perceiver felt a sensuous or aesthetic pull of great power. ${ }^{42}$

Common to both rational and aesthetic cognition in this model, however, is the striving of the mind toward a clear idea, and indeed toward an idea that mirrors the world. No matter whether one perceived the artificial signs of language or the ostensibly natural signs of music and gesture, one re-created the thing in the mind's eye. It is no coincidence that the Germans designated intuitio, commonly associated at the time with the first stage of cognition, with a word having a visual root: Anschauungschauen-"to look." The immobility of the picture served as a model of successful cognition.

Interpreters of fugue and counterpoint generally tended to privilege allegorical stasis until the end of the eighteenth century. Despite this consistency of interpretive method, however, musicians and writers could fasten onto various facets of counterpoint and fugue and work out their allegories in different ways. Originally, neo-Platonic allegories relied on congruencies between interval ratios and the ratios and numbers underpinning various metaphysical perfections. The metaphysical significance of counterpoint depended not so much on music and temporal extension as on the simplicity with which the ruling consonances could be described. A ratio of 2:3 described the interval of the fifth, but also provided the basis for an allegory of sound and world. The simplicity of a mathematical expression captured the revolutions of the spheres, the movements of the human soul, and the sounds of music. A

${ }^{42}$ David E. Wellbery, Lessing's Laocoon: Semiotics and Aesthetics in the Age of Reason (Cambridge: Cambridge University Press, 1984), pp. 9-98; Ulrich Leisinger, LeibnizReflexe in der deutschen Musiktheorie des 18. Jahrhunderts (Würzburg: Königshausen \& Neumann, 1994); Matthew Riley, Musical Listening in the German Enlightenment: Attention, Wonder and Astonishment (Aldershot: Ashgate, 2004), pp. 10-21. classic instance of this allegory was drawn from Cicero's "Dream of Scipio." It is cited, for example, by Johann Joseph Fux in the Gradus ad parnassum: "But the other eight spheres, two of which move with the same velocity, produce seven different sounds, - a number which is the key of almost everything. Learned men, by imitating this harmony on stringed instruments and in song, have gained for themselves a return to this region." 43 The planets revolved and musicians performed in time, but the link posited between musica mundana and musica instrumentalis was a static one, grounded on the immutabilities of number.

Such musica speculativa retained its hold through the eighteenth century, especially in Germany, but with the emergence of polyphony musicians interested in practical music would supplement the allegories of number derived from Pythagorean and neo-Platonic thought with allegories based on musical lines or processes. However, the tendency to seek clarity of image remained strong, no matter the imitations of nature discovered or the allegories read. Writers frequently matched the musical lines to singing angels. This approach can be traced far back. In his Treatise on the Twofold Practice of Church Music in Divine Services (Tractatus de duplici ritu cantus ecclesiastici in divinis officiis), Egidius Carlerius (ca. 13901472) noted that polyphony "is a reflection of heavenly joys. For sweet and well-constructed music conveys an image of angels and saints, unceasingly praising the name of the Lord." In his preface to a collection of part songs in 1538, Martin Luther offered a variation of this image when he wrote that the polyphonic movements of parts around a cantus firmus "seem to present a kind of divine dance so that even those of our day who have only a most limited amount of sentiment and emotion gain the impression that there exists nothing more wonderful and beautiful." 44

\footnotetext{
${ }^{43}$ Johann Joseph Fux, Gradus ad Parnassum oder Anführung zur Regelmäßigen Musicalischen Composition, trans. Lorenz Mizler (Leipzig: Lorenz Mizler, 1742), p. 34. Translation from Marcus Tullius Cicero, De re publica, De legibus, trans. Clinton Walker Keyes, Loeb Classical Library (London: Heinemann, 1928), p. 273.

${ }^{44}$ Egidus Carlerius and Johannes Tinctoris, On the Dignity や) the Effects of Music: Two Fifteenth-Century Treatises,
} 
By the beginning of the eighteenth century, writers increasingly favored more technically precise allegories, perhaps influenced by Cartesian or later forms of rationalism. In the introduction to his Harmonologia musica (1702), Andreas Werckmeister first detailed the neoPlatonic scheme. Then, however, he related the inversions of musical themes directly to the crossing of planetary paths in the heavens:

The heavens revolve and circulate steadily so that one body now moves on top but at other times changes and is found on the bottom. Indeed, this circulation is to be found in the earth and on it, and also in microcosm in man. For this reason, the philosophers say: Superius est inferius, $\oplus$ inferius est superius. We also have these mirrors of heaven and nature in musical harmony. The voice that is on top can become the lowest or middle one, and the lowest and middle voices can in turn become the highest. One voice can become all other voices and no other voice must be added, and at least four voices can be transformed in different ways in good harmony. ${ }^{45}$

Another writer to surround the technical aspects of music with a metaphysical aura was Johann Abraham Birnbaum. In his well-known defense of Bach against the journalist Johann Adolph Scheibe, Birnbaum took up the philosophical language made popular by the rationalist philosopher Christian Wolff, a follower of Leibniz. While Scheibe had criticized Bach for a lack of clear upper lines, Birnbaum defended the propriety of full-voiced polyphony using Wolff's term "perfection," a term that

ed. J. Donald Cullington and Reinhard Strohm, trans. J. Donald Cullington (London: Institute of Advanced Musical Studies, King's College, 1996), p. 27; Walter E. Buszin, "Luther on Music," Musical Quarterly 32 (1946), 82

${ }^{45}$ "Wie nun der Himmel in steter Revolution und Circulation stehet, da dasjenige, was itzo oben gehet, eine andere Zeit wieder verändert wird und unten kömt, also ist solche Circulation in und an der Erdkugel: auch an dem Menschen als Microcosmo zu finden: daher die Philosophi zu sagen pflegen; Superius est inferius, $\Theta$ inferius est superius. Diesen Himmels- und Natur-Spiegel haben wir auch in der Musicalischen harmonia, denn diejenige Stimme so da oben gehet, kann wieder die unterste und mittelere werden, und die untersten und mitleren können wieder die oberen warden." Andreas Werckmeister, Harmonologia Musica, oder Kurtze Anleitung zur musicalischen Composition (Frankfurt: Calvisius, 1702; facs. Laaber: Laaber, 2003), p. ix.
Christoph Wolff has rightly signaled as a key to Bach's music: "For music consists of harmony, and harmony becomes far more complete if all the voices collaborate to form it. Accordingly this is not a failing but rather a musical perfection." ${ }^{46}$ At least with respect to its formal qualities, a "perfection" was characterized by a high degree of inner integration. While Birnbaum did not explicitly relate Bach's music to the perfection of divine creation, the term owed its resonance and prestige at the time to debates about the perfection of God and the perfection of the created world. ${ }^{47}$ Another adherent of Wolffian precepts, Moses Mendelssohn, would ground his Principal Foundations of the Fine Arts and Sciences (1757) on the perfection of God, "the most perfect craftsman" (der vollkommenste Werckmeister). Part of the divine plan included the motivation of human action through the sensuous pleasure taken in more restricted perfections, that is, works of art. "If the cognition of such perfection is sensuous, it is called beauty." 48 Perfections in the world of art ultimately reflected back upon the perfection of creation.

A similar approach underpins each of these interpretations of counterpoint. Cosmic or metaphysical entities are made to correspond to the musical entities. The subjective experience of counterpoint is subordinated to an objective description of the organization of parts, whether the parts are mathematical ratios, thematic inversions, or well-integrated works. One notes a characteristic organization of parts at both the cosmic and the musical levels (ratio, dance, inversion, or complexity and integration), and then one posits a direct relationship between the sign of musical harmony and its metaphysical or cosmic referent. All of the writers involved were highly conscious of the rhe-

\footnotetext{
${ }^{46}$ The Bach Reader: A Life of Johann Sebastian Bach in Letters and Documents, ed. Hans T. David Arthur Mendel, rev. and supplemented edn. (New York: Norton, 1966), p. 246.

${ }^{47}$ Christoph Wolff, Johann Sebastian Bach: The Learned Musician (New York: Norton, 2000), pp. 465-72.

${ }^{48}$ "Ist nun die Erkenntniß dieser Vollkommenheit sinnlich; so wird sie Schönheit genannt." Moses Mendelssohn, "Ueber die Hauptgrunsätze der schönen Künste und Wissenschaften," in Ästhetische Schriften in Auswahl, ed. Otto F. Best (Darmstadt: Wissenschaftliche Buchgesellschaft, 1974), pp. 175-76.
} 
torical effects of music. They would never have attempted their allegories of counterpoint had the various parts not produced sensuous harmony, and harmony of a highly affecting nature. Nonetheless, the allegorical interpretation treated the relationships of the elements almost as if their temporality was not important. The atemporality of the sign was congruent with the precision of the concept, so that the interpreted thing and the allegorical process of interpretation supported each other.

Although the practice of allegory remained strong in the nineteenth and twentieth centuries, it lost prestige toward the end of the eighteenth century, becoming ever more associated with caricature and the political cartoon, only to return to a certain favor in the early twentieth century with changed epistemological and ontological presuppositions. ${ }^{49}$ The source of the loss of prestige was a new approach to interpretation. Writers on the arts began to complicate the relationship between the data provided by the senses and the ideas arrived at by the mind. The arrival of thought at a concept or idea became less important than the process of the journey. Symbol began to take the place occupied by allegory.

In a symbol, the direct substantive relation between a thing and its referent is less important than a vague but more flexible suggestiveness in the thing that ultimately can only be intuited. For Goethe, "A symbol transforms a phenomenon into an idea, and the idea into an image, and in such a way that the idea always remains infinitely effective and unattainable, and even expressed in all languages, nonetheless remains inexpressible." 50 Goethe rooted the symbol in a process of intuitive contemplation (or Anschauung) that relied for its potential on the immersion of a person in all the finer differences in the world. ${ }^{51}$ What is particularly important in the present context is the temporal-

\footnotetext{
${ }^{49}$ See Bainard Cowan, "Walter Benjamin's Theory of Allegory," New German Critique 22 (1981), 109-22.

50"Die Symbolik verwandelt die Erscheinung in Idee, die Idee in ein Bild, und so, daß die Idee im Bild immer unendlich wirksam und unerreichbar bleibt und, selbst in allen Sprachen ausgesprochen, doch unaussprechlich bliebe." Goethe, Schriften zur Kunst: Schriften zur Literatur: Maximen und Reflexionen, No. 1113.

${ }^{51}$ Kurz, Metapher, Allegorie, Symbol, pp. 69-71.
}

ity of the process: the symbol "remains infinitely effective and unattainable." Goethe's comment refers both to the mental processes of a perceiver and to the lasting untranslatability of the symbol for any interpretive community. The symbol remains veiled over time for both individual and community.

It is fair to say that one of the chief features of symbolic interpretation as it was practiced around 1800 was the central importance of subjective experience, in particular of subjective experience that depended on temporal extension for its power. When a musical work was taken as a symbol, it did not just equal another thing. Rather the work produced a certain type of experience that suggested some otherwise unavailable truth. It was precisely because the experience could not be fixed in a concept that critics were attracted to it. Such experiences flirted with the boundaries of human understanding and permitted a metaphysics that respected the achievements of the Enlightenment.

For examples of this process in interpretation, one can turn again to Christian Friedrich Michaelis. He was well equipped to deal with issues of musical technique and aesthetics at the cusp between Enlightenment and Romanticism. Michaelis had studied with Bach's successor at the School of St. Thomas in Leipzig, and he had also heard the lectures of Schiller and Fichte at the university in Jena.

Michaelis placed time at the heart of the interpretive process. In the essay "On the Sublime in Music" (1801), he addressed a variety of composers and genres typically judged sublime around 1800. He included the fugue among them, though he did not distinguish it from the symphony or other instrumental genres. ${ }^{52}$ Of the music to be found in such genres, Michaelis first posits musical passages of overwhelming power. He then writes:

Faced by such a fast and seemingly endless change of sensations, by such an unstoppably rushing and disappearing quantity of impressions, by such speedy,

\footnotetext{
${ }^{52}$ Later in his career Michaelis distinguished between genres more finely, for instance, in the essay "Etwas zur Rechtfertigung des Contrapunctes" (1817), which appeared in the Allgemeine musikalische Zeitung mit besonderer Rücksicht auf den österreichischen Kaiserstaat.
} 
similar though unusual movements, the imagination knows how to find neither beginning nor end, and can find no place to stand firm. This transporting stream of changes has something terrible about it. At once it is now an image of the evanescence of life and the threatening power of nature, now an image of eternity. It fills the soul with sublime sentiments when the soul has assured itself and, through reason, risen above the power of mere appearances. ${ }^{53}$

Time here enters into play in three ways. First, there is a series of events that leads the mind from its initial state of mental balance to a terrifying breakdown and then to an exhilarating recovery. This three-stage experience-balance, breakdown, and recovery-provokes the mind to imagine great things. ${ }^{54}$ Second, the transcendentals toward which the music points are those that emphasize the temporality of human existence, namely evanescence and eternity, common themes in the arts for centuries to be sure.

Third, the musical images circulate in the imagination of the ideal listener. To repeat the essential phrase about the stream of changes: "At once [zugleich] it is now [bald] an image of the evanescence of life and the threatening power of nature, now [bald] an image of eternity." In this paraphrase of traditional topoi of sublimity, music provides the images of evanescence and eternity both at once and one after the other. The slippage between simultaneity and succession generated by the words

\footnotetext{
53"Bey einem so schnellen, unaufhörlich scheinenden Wechsel der Empfindungen, bey einer so unaufhaltsam vorüberrauschenden und dahinschwindenden Menge von Eindrücken, bey so geschwinden gleichförmigen (aber doch ungewohnten) Bewegungen, weiß die Einbildungskraft weder Anfang, noch Ende zu fassen, sich nirgends fest zu halten: dieser hinreißende Strom der Veränderung hat etwas Furchtbares, ist zugleich bald ein Bild der Flüchtigkeit des Lebens und der drohenden Macht der Natur, bald ein Bild der Ewigkeit, und erfüllt die Seele, wenn sie sich dabey doch ermannt und durch Vernunft über die Gewalt bloßer Erscheinungen erhebt, mit erhabenen Empfindungen." Christian Friedrich Michaelis, Ueber den Geist der Tonkunst und andere Schriften, ed. Lothar Schmidt (Chemnitz: G. Schröder, 1997), p. 169. The essay appeared in the Monatsschrift für Deutsche.

${ }^{54}$ Michaelis drew his psychology of the sublime from Kant For an analysis of the stages involved in Kant's theory of sublimity, see Thomas Weiskel, The Romantic Sublime: Studies in the Structure and Psychology of Transcendence (Baltimore: Johns Hopkins University Press, 1976), pp. 23 24.
}

"at once" (zugleich) and "now" (bald) indicates the powerful indeterminacy underpinning the symbol and distinguishes it from the significations of allegory. The same slippages illustrates the way that symbolic understanding, as it was understood by many writers from Kant onward, depended on the process of thought, not on its crystallization in clear concepts.

It was not just the philosophically minded music critic who favored process in interpretation. A poetic enthusiast of counterpoint could provide the material for a similar approach. In 1827 Albert Kiekebusch contributed two poems, Der Kontrapunkt and Der endliche Kanon [sic], to Adolf Bernhard Marx's Berliner allgemeine musikalische Zeitung. Der Kontrapunkt is of particular interest. It draws explicitly on Baroque images and allegory, yet develops them in ways that undermine the stasis of the allegory:

\section{Counterpoint}

"What is it?" ask many tongues,

Yet it is for them an incomprehensible word, Even if the master, thoroughly permeated by it, Rips aside the curtain that shields their eyes. For it has sprung from higher being,

And no human being arrives at its holy place If he has not first strengthened his soul, And anointed himself with the oil of true wisdom.

"What is it?" That is known above all by those

To whom is directed the high master's word And whom the Lord, according to his pleasure, Illuminated with the light of his wisdom.

Her foot steps out into the richly decorated halls And she looks to them, full of confidence,

She who is eternally enthroned in the eternal clarity of the stars

And who hands the wreath of truth delicately down.

There the spirit looks at her on her throne, The body only measures his space; She carries the sevenfold $\left({ }^{\star}\right)$ transfigured crown, Just as he reveals the eternal dream of life:

Of the pain of life, of the lot of man to be scorned

He gives proof on the hem of his gown,

For just as misfortune and pain can turn, So he can be turned away. 
Let now the layfolk say what they say, To us it is all the same. We are shielded! Let all without fear dare us with the masses, Who once listened to us, yes, only to us. On his wings he will one day carry us To her, to her, the sister unscathed, There, only she alone will speak her voice, There, only he alone will rule.

${ }^{*}$ ) Following Jakob Böhm. According to his theosophical point of view, music will be transfigured sevenfold. [Footnote in original.]

\section{Der Kontrapunkt}

Was er wohl sei-das fragen viele Zungen, Doch ist's für sie ein unverständlich Wort,

Wenn auch der Meister, stark von ihm durchdrungen,

Vor ihren Augen reifst den Vorhang fort.

Denn aus dem höhern Sein ist er entsprungen,

Und kommt kein Mensch zu seinem heil'gen Ort

Er hab' zuvor gestärket seine Seele, Und sich gesalbt mit rechter Weisheit Oele.

Was er wohl sei-das wissen die vor allen An die des hohen Meisters Wort gericht't $t$, Und die der Herr, nach seinem Wohlgefallen Umleuchtete mit seiner Weisheit Licht. Ihr Fuss betritt die reichgeschmückten Hallen Und auf sie schauet Sie voll Zuversicht, Die ewig thront in ew'ger Sternenklarheit

Und reicht hernieder mild den Kranz der Wahrheit.

Dort schauet Sie der Geist auf ihrem Throne, Der Körper nur ermisset seinen Raum; Sie trägt die siebenfach $\left(^{\star}\right)$ verklärte Krone, Wie er enthüllt des Lebens ew'gen Traum:

Des Lebens Schmerz, des Menschen Loos zum Hohne

Giebt er Beweis an seines Kleides Saum,

Denn wie sich wenden Unglück und Beschwerden,

So auch kann er von uns gewendet werden.

Lass denn die Laien sagen, was sie sagen, Uns sei es alles gleich, wir sind bewährt! Lasst All' getrost uns durch die Menge wagen, Die einstens doch auf uns, auf uns nur hört. Auf seinen Flügeln wird er einst uns tragen $\mathrm{Zu} I h r$, zu Ihr, der Schwester unversehrt, Dort wird nur Sie allein die Stimme führen, Dort wird nur einzig er allein regieren. ${ }^{55}$

\footnotetext{
${ }^{55}$ Albert Kiekebusch, "Der Kontrapunkt," Berliner allgemeine musikalische Zeitung 4 (1827), 316 (emphases in original).
}

( ${ }^{\star}$ Nach Jakob Böhme. Seiner theosophischen Einsicht zufolge wird die Musik siebenfach verklärt werden.

Kiekebusch used religious imagery to paint counterpoint as an entity beyond human ken. Whereas the specialist might be guided by it toward unimaginable riches, the layperson will find it ever strange. With these observations Kiekebusch took up familiar topoi from the Romantic aesthetics of counterpoint. They had been made popular among musically educated members of the middle classes, above all by E. T. A. Hoffmann. ${ }^{56}$ Counterpoint has a revelatory power for those willing to contemplate it.

In positioning counterpoint as revelatory, however, the poem engages a symbolic mode of interpretation that obscures the revelation and subverts the allegory associated with it. The debt Romantic music critics owed to sixteenthand seventeenth-century religious writers is well known. ${ }^{57}$ What is significant about this particular poem is the way traditional allegories are rendered opaque through suggestion. Initially the poem captures the elusiveness of counterpoint through allegory. Counterpoint is personified, outfitted with religious pathos, and positioned as an entity that guides the specialist musician but remains veiled to the unknowing masses. As the poem continues, however, the web of personal pronouns grows ever denser and ever more difficult to penetrate. Counterpoint (der Contrapunkt) is masculine, as are a number of other agents throughout the poem: the Lord, the Spirit, the body. It is often difficult to ascertain to what or to whom the masculine pronouns (er, sein) refer, but study (and translation) can clarify their referents, perhaps more than Kiekebusch would have liked. When the feminine pronoun ihr and sie arrive in lines 13-14, allegory turns toward symbol, for the

\footnotetext{
${ }^{56}$ See, for example, Kreisler's performance of Bach's "Goldberg" Variations in the first of Hoffmann's Kreisleriana. E. T. A. Hoffmann, Fantasie- und Nachtstücke, 6th edn. (Düsseldorf: Artemis \& Winkler, 1996), pp. 27-32; Hoffmann, Musical Writings, pp. 81-87. ${ }^{57}$ Dahlhaus, The Idea of Absolute Music, trans. Roger Lustig (Chicago: University of Chicago Press, 1989), pp. 88-102; Mark Evan Bonds, "Idealism and the Aesthetics of Instrumental Music at the Turn of the Nineteenth Century," Journal of the American Musicological Society 50 (1997), 387-420.
} 
referent of the pronoun is not named. Capitalization and emphasis reinforce the centrality of the female figure even as her name is withheld. The interpreter is left to consider the possibilities.

The plurality of those possibilities is a sign that the poem has undermined the allegorical mode with which it began. There are at least two lines of significance, though the lack of a referent for the feminine pronoun leaves more lines open. The first is suggested by indications within the text of the poem. The heavy use of Christological images suggests that the Virgin Mary is the presiding figure. The second prospect is musical and is named by Kiekebusch's footnote: die Musik.

The doctrinally specific implication /the Virgin Mary) is rendered opaque at the end of the poem with the invocation of a sister-brother relationship between feminine and masculine pronouns. The Virgin Mary cannot be a sister to any of the possible male protagonists. But although the masculine and feminine pronouns refer best to "counterpoint" and "music," respectively, they never entirely exclude the standard characters of religious doctrine. The ambiguities are especially rich in the final two lines. Because "voice" (Stimme) has both linguistic and musical meaning, the lines could refer to the technical relationship between counterpoint (masculine) and music (feminine): music speaks, but counterpoint rules her speaking. Or the lines could refer to the function of counterpoint in the training of the expert musician: counterpoint rules the path to the metaphysical utterances of which music is capable.

As to the footnote, it nominally brings greater clarity to the poem but does not entirely resolve its symbolic resonances. Not only is it unclear who wished the note printed-the author Albert Kiekebusch or the editor Adolf Bernhard Marx-but the clarification offered by the note does not erase the elusiveness and allusiveness of the play of pronouns. The difficulty of interpretation seems to be one of the points of the poem, and the explanatory footnote both simplifies and complicates the process.

The degree to which the poem strives against allegory can be seen from a brief comparison with the stated mentor, Jakob Böhme. The com- parison also serves as a reminder of the intellectual distance that writers on the arts had traveled by the early nineteenth century. Böhme (1575-1624) was a Lutheran mystic influential on Romantic writers, especially Friedrich Schlegel and Novalis, whom he served primarily as an inspiration in their challenge to the boundaries that Kant had placed on metaphysical thought. They did not take Böhme as an example of how to write or read. When Böhme revealed transcendent truths, he used the clarity of allegory to paint definite pictures. Bouquet of Jakob Böhme's Writings, published in 1819 , begins with an allegory that gives the flavor of the mystic's writings: "The tower in the great city of Babel is an image of fallen mortal man who has receded into himself and who has made the word of God into an idol." 58 While the allegory might be strange, its presentation is clear and its meaning is spelled out. It requires only the person with proper theological vision to decipher it-a specialist of the stripe of Böhme himself. Kiekebusch's Romantic mysticism, by contrast, revels in a vagueness that leaves interpretation open to many, even as it compliments the cohort of interpreters by counting them among the initiated.

\section{A Revolution in Method}

There are several reasons that German writers on the arts began to insist on the process involved in thought and interpretation toward the end of the eighteenth century. The first reason is philosophical. Whereas writers on aesthetics from Alexander Baumgarten onward had given ever greater importance to cognitions of the senses, Immanuel Kant decisively changed the playing field of aesthetics through the role he gave to the mind in constituting the framework for perception and understanding. Goethe, Schiller, Reinhard, Novalis, the Schlegel brothers, and many educated Germans of lesser re-

\footnotetext{
58"Der Thurm bei der großen Stadt Babel ist ein Bild des abgefallenen irdischen Menschen, der in die Selbstheit eingegangen ist, und das Wort Gottes in ihm zu einem Abgott gemacht hat." Blumenlese aus Jacob Böhmens Schriften, ed. J. G. Rätze (Leipzig: Hartmann, 1819), p. 1. Accessed through Google Books. I have been unable to find the discussion of music by Böhme to which the footnote refers.
} 
nown reviewed and reworked this "Copernican Revolution," as Kant called it. ${ }^{59}$ The results were many, but not least among them was the prominence given the imagination as a productive capacity. ${ }^{60}$ One found pleasure in the contemplation of an artwork because one's mind worked in a particular way. An aesthetic idea, Kant wrote, "is that representation of the imagination that incites much thinking, without there being a determinate thought (that is, a concept) that is adequate to it. As a result, no language fully attains it or makes it intelligible." ${ }^{\prime 61}$ The potential lack of correspondence between the imagination and concepts is what motivates the processual side of aesthetic experience. Schiller summed up the effect that Kant had had on educated Germans when he wrote that "a revolution in the philosophical world has shaken the foundations on which aesthetics had been based and has thrown the existing system, if one can call it that, to the dogs." 62

Another reason for the turn toward process in interpretation involves the hardening of the work concept. Allegory had ruled in an era when musicians thought primarily about the effects of music, either through the lens of the

\footnotetext{
${ }^{59}$ Kant, Kritik der reinen Vernunft, I, 27 (Akademie Ausgabe B, xvi-xvii).

${ }^{60}$ Andrew Bowie, Aesthetics and Subjectivity from Kant to Nietzsche (New York: St. Martin's Press, 1990), pp. 1-7.

${ }^{61}$ "Unter einer ästhetischen Idee aber verstehe ich diejenige Vorstellung der Einbildungskraft, die viel zu denken veranlaßt, ohne daß ihr doch irgendein bestimmter Gedanke, d. i. Begriff, adäquat sein kann, die folglich keine Sprache völlig erreicht und verständlich machen kann." Immanuel Kant, Kritik der Urteilskraft, ed. Karl Vorländer (Hamburg: Meiner, 1990), pp. 167-68 (\$49).

${ }^{62}$ Letter of 9 February 1793 to Friedrich Christian von Schleswig-Holstein-Sonderburg-Augustenburg. "Die Revolution in der philosophischen Welt hat den Grund, auf dem die Aesthetick aufgeführt war, erschüttert, und das bisherige System derselben, wenn man ihn anders diesen Nahmen geben kann, über den Haufen geworfen." Friedrich Schiller, Werke: Nationalausgabe, ed. Julius Petersen, et al. (Weimar: Hermann Böhlaus Nachfolger, 1940-), XXVI, 184. For discussions of Kant's influence on music criticism, especially with respect to the work concept, see Wilhelm Seidel, "Zwischen Immanuel Kant und der musikalischen Klassik: Die Ästhetik des musikalischen Kunstwerks um 1800," in Das musikalische Kunstwerk: Geschichte, Ästhetik, Theorie: Festschrift Carl Dahlhaus zum 60. Geburtstag, ed. Hermann Danuser, et al. (Laaber: Laaber, 1988), pp. 67-84; Lothar Schmidt, Organische Form in der Musik: Stationen eines Begriffs 1795-1850 (Kassel: Bärenreiter, 1990).
}

humanist "praise of music" or through that of a rhetoric of persuasion or affect. Although the significance of counterpoint could be ascertained as something that existed independently of time, its effects were to be discovered in the time-bound performative practices of musical production and reception. By contrast, by the end of the eighteenth century, artists sought to extricate the work as a conceptual entity from these practices of production and reception, in essence to withdraw the work from time. The flip side of this reification of the work was that interpretation itself became more of a process. Musicians strongly oriented toward works posited the work itself as closed and hermetic but found the process of interpretation fluid.

This separation of reified work and flux of interpretation was described by Michaelis in On the Spirit of Music, with Consideration of Kant's Critique of Aesthetic Judgment: An Aesthetic Essay (1795). Michaelis first noted that the imagination could construe an imaginative entity-"a new world, as it were" Igleichsam eine neue Welt)—by construing its sensory experiences. ${ }^{63}$ Like other writers of the late eighteenth century, he used the philosophical concept of alternative worlds to conceptualize the self-contained work. ${ }^{64}$ This act of imagination could be followed by a second stage in which the imagination was set alight by vague but significant ideas: "A piece of music comes to life when the energy and the characteristic quality in the harmony and melody awaken unnamable feelings and ideas [Gefühle und Vorstellungen] in us and, as it were, carry us up into a celestial sphere." Finally, Michaelis enthused about possible interpretations and the range of moods that such ideas produce. "A single expression in the poet's language, a single facial trait in a painting or a sculpture, or a single tone in music can awaken an infinite

\footnotetext{
63"Die Einbildungskraft schafft sich gleichsam eine neue Welt durch analogische zusammensetzung, Vergrößerung oder Verringerung und manchfaltige Abänderung der Gegenstände der wirklichen Natur." Michaelis, "Ueber den Geist der Tonkunst: Mit Rücksicht auf Kants Kritik der ästhetischen Urtheilskraft. Ein ästhetischer Versuch," in Schriften, p. 7

${ }^{64}$ Dahlhaus, "'Eine abgesonderte Welt für sich selbst,'" in Klassische und romantische Musikästhetik (Laaber: Laaber, 1988), pp. 144-49.
} 
variety of the most interesting ideas and can bring forth the most affecting moods." 65

Michaelis was after something difficult to describe, and once again it is possible to read his meaning from the slippages in his language. The slippages arise from the complexity of the interpretive process he wished to describe. He says first that ideas cannot be captured in words. They are unnamable. Then he describes their infinite variety. The slip from elusiveness to infinity is a token of the directional process involved in symbolic interpretation. Michaelis seems to have two types of ideas in mind. The first is encoded in the musical work and cannot be consummated by language. The second is more precise but is of a second order. Because it only approximates the first type of idea, it is endlessly replaceable by other second-order ideas. Taking flight from a significance divined rather than defined, the imagination is left to wander wide fields.

To summarize, there are two homologies involved in the relationship between the keyboard fugue and time. There is a homology between the techniques of fugue and the interpretive method used to find metaphysical significance in counterpoint generally, and there is a homology between these two issues taken together and the historical sensibilities of the early eighteenth and the early nineteenth centuries, respectively. If the keyboard fugue always tended toward the cyclical, it could nonetheless be invested with varying degrees of teleological drive, especially once German composers began to stage dramatic transformations or events in order to suit the nineteenth-cen-

\footnotetext{
${ }^{65}$ "Ein Tonstück ist vom Geist ästhetischer Ideen belebt, wenn die Energie und das Charakteristische in Harmonie und Melodie unnennbare Gefühle und Vorstellungen der Einbildungskraft in uns wecken und uns gleichsam in eine überirdische Sphäre emporschwingen. Ein einziger Ausdruck in der Sprache des Dichters, ein einziger Gesichtszug in dem Gemälde oder in der Bildsäule, ein einziger Ton in der Musik, kann eine zahllose Menge der interessantesten Vorstellungen wecken und die rührendeste Stimmung hervorbringen." Michaelis, Schriften, pp. 7-8 (emphases added).
}

tury taste for teleology. But no matter where a fugue stood on the continuum between stasis and flux, composers were only partly responsible for the significance read into their works. Writers on counterpoint on both sides of the century spoke of counterpoint and fugue in terms of transcendence, but their ways of thinking about such transcendence were quite different. The practices of interpretation were attuned to the temporal character of the music. The favor shown by Bach to cyclical, timeattenuating musical processes was matched by the favor lavished by his contemporaries on the precisions and objective analyses of allegory. By contrast, Schumann presents a succession of states through which time seems to move forward. The increasing popularity of teleological drives in his time was underpinned by the flexible vagaries of the symbol. Schumann staged a process that would overwhelm his listeners, fill them with sublime sentiments, and leave them with intimations of eternity and other transcendentals that were powerful in proportion to their vagueness.

\begin{abstract}
.
Throughout the history of Western music, musicians have almost invariably discussed the keyboard fugue and other extreme forms of polyphony as signs of something that transcends human subjectivity. Despite the persistence of this critical topos, musicians shifted their approach to it around the beginning of the nineteenth century. The shift involved both a change in the technique of counterpoint and a change in the way counterpoint was interpreted. Composers sought to invest the fugue with a new dramatic and teleological thrust suitable to modern times, and critically minded musicians changed their interpretive method so as to emphasize the passage of time. Whereas musicians of the early eighteenth century read counterpoint and the fugue allegorically and annulled time through the conceptual precision of the allegorical image, musicians of the late eighteenth and early nineteenth centuries read the fugue symbolically and worked time into their interpretive process. In both eras, the practice of interpretation coincided with and affected the reading of the genre's temporality. Key words: fugue, allegory, symbol, Robert Schumann, Johann Sebastian Bach, Christian Friedrich Michaelis, Immanuel Kant
\end{abstract}

